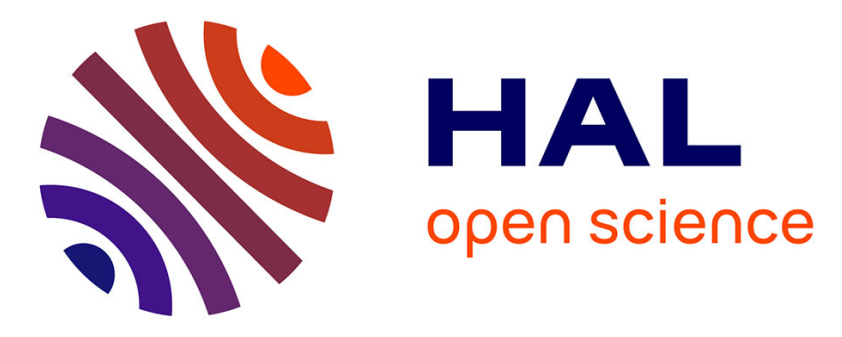

\title{
Impacts of low doses of pesticide mixtures on liver cell defence systems
}

\author{
Patrick Rouimi, Nathalie Zucchini-Pascal, Gwendoline Dupont, Andrej \\ Razpotnik, Edwin Fouché, Georges de Sousa, Roger Rahmani
}

\section{- To cite this version:}

Patrick Rouimi, Nathalie Zucchini-Pascal, Gwendoline Dupont, Andrej Razpotnik, Edwin Fouché, et al. Impacts of low doses of pesticide mixtures on liver cell defence systems. Toxicology in Vitro, 2012, 26 (5), pp.718-726. 10.1016/j.tiv.2012.03.015 . hal-02645075

\section{HAL Id: hal-02645075 \\ https://hal.inrae.fr/hal-02645075}

Submitted on 29 May 2020

HAL is a multi-disciplinary open access archive for the deposit and dissemination of scientific research documents, whether they are published or not. The documents may come from teaching and research institutions in France or abroad, or from public or private research centers.
L'archive ouverte pluridisciplinaire HAL, est destinée au dépôt et à la diffusion de documents scientifiques de niveau recherche, publiés ou non, émanant des établissements d'enseignement et de recherche français ou étrangers, des laboratoires publics ou privés. 


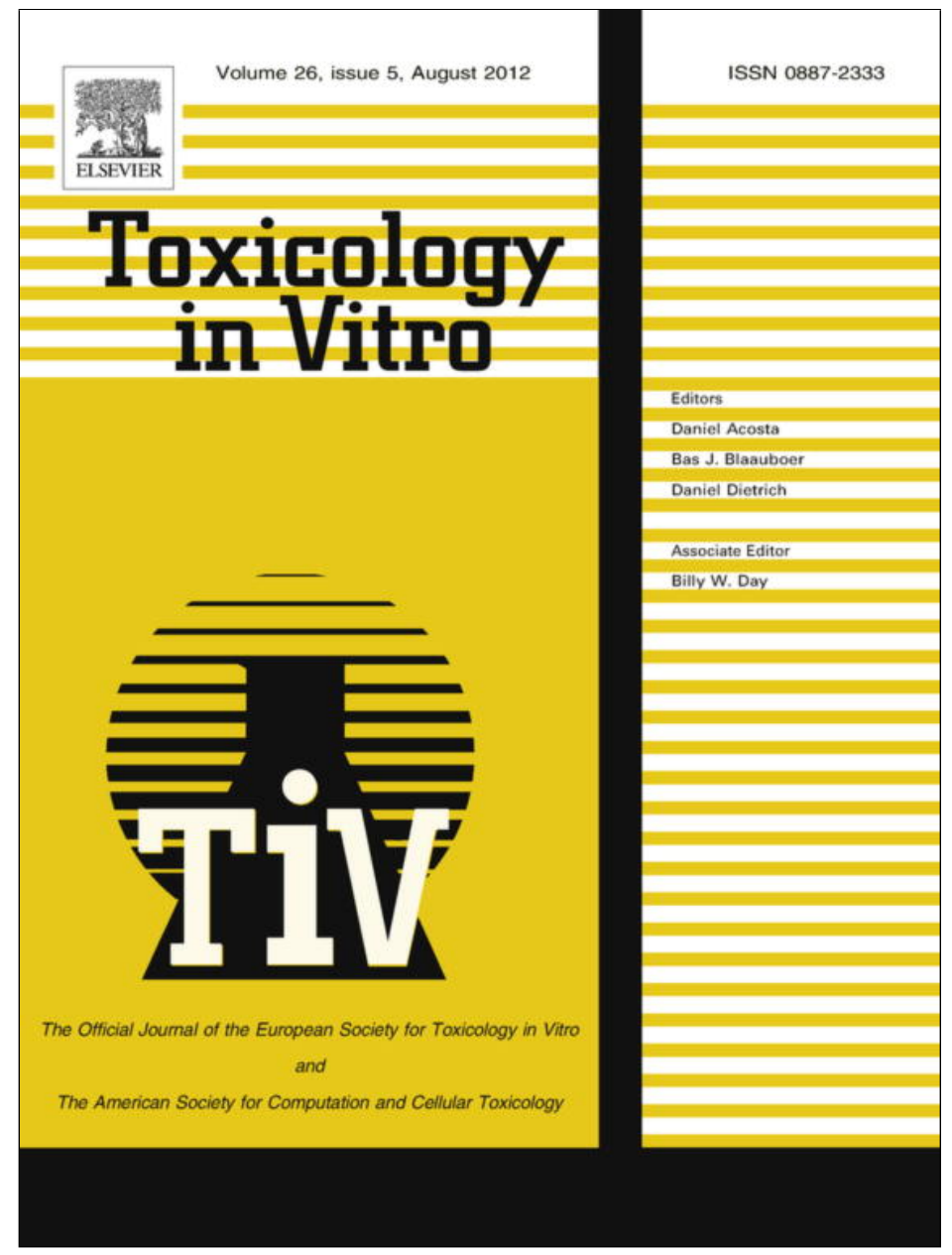

This article appeared in a journal published by Elsevier. The attached copy is furnished to the author for internal non-commercial research and education use, including for instruction at the authors institution and sharing with colleagues.

Other uses, including reproduction and distribution, or selling or licensing copies, or posting to personal, institutional or third party websites are prohibited.

In most cases authors are permitted to post their version of the article (e.g. in Word or Tex form) to their personal website or institutional repository. Authors requiring further information regarding Elsevier's archiving and manuscript policies are encouraged to visit:

http://www.elsevier.com/copyright 


\title{
Impacts of low doses of pesticide mixtures on liver cell defence systems
}

\author{
Patrick Rouimi $^{\mathrm{a}, *, 1}$, Nathalie Zucchini-Pascal ${ }^{\mathrm{b}, 1}$, Gwendoline Dupont $^{\mathrm{a}}$, Andrej Razpotnik ${ }^{\mathrm{b}}$, Edwin Fouché ${ }^{\mathrm{a}}$, \\ Georges De Sousa ${ }^{b}$, Roger Rahmani ${ }^{\mathrm{b}}$ \\ ${ }^{a}$ Institut National de la Recherche Agronomique (INRA), UMR 1331 TOXALIM (Research Centre in Food Toxicology), 180 chemin de Tournefeuille, F-31027 Toulouse, France \\ ${ }^{\mathrm{b}}$ Institut National de la Recherche Agronomique (INRA), UMR 1331 TOXALIM (Research Centre in Food Toxicology), 400 route des Chappes, BP 167, F-06903 Sophia-Antipolis, France
}

\section{A R T I C L E I N F O}

\section{Article history:}

Received 20 September 2011

Accepted 29 March 2012

Available online 9 April 2012

\section{Keywords:}

Pesticides mixture

Liver

Hepatocytes

HepaRG

Apoptosis

Metabolic pathways

\begin{abstract}
A B S T R A C T
Low amounts of residual pesticides are present in the environment, often as mixtures of chemicals which contaminate drinking water and food, being a source of chronic exposure for humans and a growing matter of concern in public health policy. Despite of the needs and growing investigation, little is known about the impact of low doses and mixtures of these chemicals on human health. The purpose of this study was to enlighten if modifications of liver cell metabolic- and/or defence-related capacities could occur under such exposures. In vitro perturbations of several metabolic, stress and survival pathways in human and mice cultured hepatocytes and liver cells were evaluated under exposure to low doses of single molecules or equimolecular combinations of the three pesticides, atrazine, chlorpyrifos and endosulfan. Mainly phases I and II enzymes of detoxification were found modulated, together with apoptotic process deregulation. Hence, CYP3A4 and CYP3A11 were upregulated in primary cultured human and mouse hepatocytes, respectively. These inductions were correlated to an anti-apoptotic process (increased Bcl-xL/Bax ratio, inhibition of the PARP protein cleavage). Such disturbances in pathways involved in cell protection may possibly account for initiation of pathologies or decrease in drugs efficiency in humans exposed to multiple environmental contaminants.
\end{abstract}

(C) 2012 Elsevier Ltd. All rights reserved.

\section{Introduction}

Chemicals used in agricultural settings, public health and individual households include a large variety of active substances that enter the composition of various authorized commercial preparations. Although essential for agricultural development and food resources control, pesticides remain as residual contaminants in various compartments of the environment.

Indeed, humans are exposed to multiple chemical compounds. Routes of exposure are multiple (ingestion, respiration, skin contact) based on different scenarios or situations, food being an important source of contamination. The consequences of such exposures on human health are complex and still poorly understood, making risk assessment of any toxic effects of chemical mixtures on human health uneasy and a particularly accurate process. Major difficulties in the assessment of exposures to cocktails of pesticides is due to differences in the levels, the periods of

Abbreviations: ADI, acceptable daily intake; ATM, ataxia telangiectasia mutated; BCL2, B cell lymphoma 2; BRCA1/2, breast cancer 1 and 2, early onset proteins; CHEK2, checkpoint kinase 2; GST, glutahione S-transferase; CYP, cytochrome P450; H2AX, histone H2A-member X; TBP, TATA-binding protein; Tnfsf10 (TRAIL), tumor necrosis factor related apoptosis inducing ligand.

* Corresponding author. Tel.: +33 561285 393; fax: +33 561285244.

E-mail address: prouimi@toulouse.inra.fr (P. Rouimi).

1 These authors contributed equally to this work. exposure and their simultaneous and/or sequential occurrence, the complexity and the diversity of active substances (regarding toxicity), but also of adjuvant used in products processing and agronomical uses.

Pesticides are designed to selectively eliminate various pests among fungi, plants or animals. They usually target specific biological functions of the pest through disruption of vital cellular pathways. Their mechanisms of action are tightly linked to their chemical structures which are widely diversified. Potent toxicity for humans is carefully evaluated by the authorities from premarket in vitro studies or in vivo experiments in animals carried out with pesticides tested individually. Safety norms, established from various experimental and epidemiological studies, are then prescribed through legal exposure thresholds such as the Acceptable Daily Intake (ADI), in order to protect human health.

Acute professional exposure to pesticides provided data showing a correlation with several human pathologies, including hepatotoxicity, immunotoxicity, increased risk of mainly haematopoietic, brain and prostate cancers (Purdue et al., 2007; Mahajan et al., 2006; Ruder et al., 2006), neuro-degenerative diseases such as Parkinson's disease (Liu et al., 2003; Baldi et al., 2003; Alavanja et al., 2004; Chade et al., 2006) and deficiencies in cerebral development (Mendola et al., 2002) or immunity (Colosio et al., 2005). Household exposure to pesticides is more and more described as a significant risk (Abadi-Korek et al., 2006; Weselak et al., 2007), 
but the most important source of contamination for the consumer remains food and cocktails of pesticides ingested every day.

Several studies, mainly epidemiological, have described pesticides as potentially deleterious for human health. In the present work, three pesticides (chlorpyrifos, atrazine and endosulfan) were selected for in vitro toxicological investigations at low doses, mainly because of their persistence in the environment and food or their acute toxicity when tested in vivo on animal models.

Atrazine (2-chloro-4-ethylamine-6-isopropylamino-S-triazine) is a systemic triazine herbicide which was mainly used to destroy weeds in maize and rapeseed cultures, but also as algaecide in aquariums. It was banned in the EU in 2004 because of its persistence in groundwater (Ackerman, 2007). In France, atrazine is still a drinking water contaminant. This herbicide has been shown to exert neurotoxic effects even at very low doses (Cooper et al., 1999; Rodriguez et al., 2005) and to possess immunotoxicological potential, especially in perinatal exposures (Rusiecki et al., 2004; Rowe et al., 2006, 2008). It also increased incidence of mammary tumors (Eldridge et al., 2008). Ingested pesticides from the triazine family appeared to affect development in laboratory animals and humans. Epidemiological studies supported developmental or reproductive toxicity of atrazine in humans (Villanueva et al., 2005) and initiation of haematopoietic cancers (Rusiecki et al., 2004). Moreover, various laboratory studies indicated that atrazine adversely affects fetal implantation in rats (Cummings et al., 2000). Other data showed that chronic exposure to low concentrations of atrazine induced abdominal obesity and insulin resistance in rats by impairing mitochondrial function (Lim et al., 2009). Recent data showed that prenatal exposure to atrazine metabolites were active on postnatal reproductive development of male rats (Stanko et al., 2010).

Chlorpyrifos is an organophosphorus insecticide widely used in agriculture and households. Chlorpyrifos and its metabolite chlorpyrifos-oxon toxically target the central nervous system by inhibiting acetylcholinesterase (Whitney et al., 1995; Chakraborti et al., 1993). Authors have reported that chlorpyrifos caused immunologic abnormalities in humans (Thrasher et al., 2002; Galloway and Handy, 2003) and animals (Navarro et al., 2001). It was also associated with autoimmune diseases (Thrasher et al., 2002), multiple chemical sensitivity and rectal cancer (Lee et al., 2007). Growing body of evidence demonstrated that chlorpyrifos and other organophosphates possessed endocrine disruptor properties at low doses (Haviland et al., 2010).

Endosulfan is one of the most toxic pesticides still in use in the world. It was already banned in several countries but is still intensively used in Asia (i.e., India and China). It is basically a neurotoxic organochlorine insecticide and acaricide which is persistent in the environment. In laboratory animals, endosulfan has been shown to be toxic to the liver, kidneys, the nervous system, and reproductive organs (Gupta and Chandra, 1977; Hack and Leist, 1995; Paul et al., 1995; Sinha et al., 1997). These effects have been attributed to increased oxidative stress caused at least by a modification of expression of antioxidant enzymes, including superoxide dismutase (SOD), glutathione peroxidase (GPX) and glutathione $S$ transferase (GST) (Bebe and Panemangalore, 2003). Endosulfan exposure increased cytochrome P450 (CYP) levels in vivo in both hepatic and extra-hepatic tissues (Siddiqui et al., 1987), as well as in human hepatocytes in vitro (Lemaire et al., 2004). Furthermore, it showed endocrine disruptor properties in rodents, and its endocrine disrupting effects in humans are a concern (Silva and Gammon, 2009). In developing and adult rats, endosulfan induced testicular toxicity and damage, including abnormal spermatozoa, and decreased sperm counts and motility (Rao et al., 2005). In rodents, endosulfan treatment led to increased testosterone metabolism and clearance (Singh and Pandey, 1990; Wilson and LeBlanc, 1998). Moreover, the occurrence of early and late apoptotic/necrotic processes in SH-SY5Y human neuroblastoma cells or disruption of cerebral cortical in rats treated with low doses of endosulfan supported its involvement in neurodegenerative diseases (Jia and Misra, 2007; Scremin et al., 2011).

The liver is an essential organ involved in the metabolism of endogenous or exogenous substances. Most of xenobiotics are metabolized in the liver by detoxification processes involving several activation, conjugation and elimination mechanisms. Multiplicity and chronicity of xenobiotics exposures induce simultaneous modulations of various cross-reactive cellular pathways. On another hand, evaluation of the impact of chronic exposure to low doses and combinations of residual environmental contaminants on humans is still uncertain and very difficult to set up in term of regulation (Alavanja et al., 2004). Some authors described severe endocrine disruptions due to pesticides exposure at very low environmental doses (Hayes et al., 2002). Additionally, non-linear dose-response toxicity can be observed and combinations with other POPs or differences in individual susceptibility may increase the effects (Calabrese, 2010; Lutz, 2002). As a consequence, effects of pesticides and combinations of pesticides have to be studied carefully at very low doses.

Besides its metabolic functions, the liver may also constitute a target for toxic xenobiotics. In a previous study, we observed that a mixture of twelve pesticides administered at doses corresponding to human ADI was not carcinogenic in a rat liver model of chronic exposure (Perez-Carreon et al., 2009). These data enlighten difficulties to observe clear evidences for toxicity of chronic low dose exposures to pesticide mixtures through phenotypical changes in vivo. Another of our investigations, examining the role of nuclear receptor (NC) activation in human and rat hepatocytes exposed to Pregnane X Receptor (PXR) activators, suggested that PXR may protect the liver against chemicals by simultaneously regulating detoxification and the apoptotic pathway (Zucchini et al., 2005). The present work evaluates in vitro perturbations at the mRNA and protein levels of several stress and toxicity related cellular pathways in various hepatic cells ranging from animal and human hepatocytes to human hepatocarcinoma-derived cell models, following exposure to low doses of single molecules or equimolecular combinations of atrazine, chlorpyrifos and endosulfan.

The slight modifications induced by pesticides in liver cell metabolic and/or defence capacities revealed in this study may help to better understand mechanisms by which multiple environmental contaminants exposure could interfere with cellular pathways which could be of importance in health or drug efficiency status in humans.

\section{Material and methods}

\subsection{Materials}

\subsubsection{Chemicals}

The pesticides, Atrazine, Chlorpyriphos, and Endosulfan, were purchased above 98\% purity from Sigma-Aldrich (Saint Quentin Fallavier, France). DMSO was from Sigma-Aldrich. All other chemicals and reagents used were of analytical grade.

\subsubsection{Antibodies (Abs)}

Mouse monoclonal antibody $(\mathrm{Ab})$ to $\mathrm{Bcl}-2$ (clone $\mathrm{Ab}-1$ ) was from Oncogene (Boston, USA); Rabbit polyclonal Ab to Bcl-xL was from Transduction Laboratories (Lexington, KY, USA); Rabbit polyclonal Abs to human were from Oxford Biomedical Research (Oxford, MI, USA); Rabbit polyclonal $\mathrm{Ab}$ to $\mathrm{Bax}$ and rabbit monoclonal Ab (clone 46 D11) were from Cell Signaling (Beverly, MA, USA). Blots were reprobed with rabbit monoclonal Ab to Gapdh (clone 14C10) from Cell Signaling. 


\subsection{Cell culture and treatments}

Various hepatic cells were used in our experiments: the HepaRG ${ }^{\mathrm{TM}}$ immortalized human hepatic cell line and primary cultured human and mouse hepatocytes.

HepaRG cells were grown and maintained as already described (Gripon et al., 2002; Aninat et al., 2006). Briefly, the William's E medium with s-glutamine (Invitrogen, Life Technologies SAS, Saint Aubin, France), supplemented by $10 \%$ fetal calf serum (PAA, Les Mureaux, France), $0.1 \mathrm{U} / \mathrm{ml}$ insulin (Lilly Pharma, Giessen, Germany), $5 \mu \mathrm{M}$ hydrocortisone hemisuccinate (Sigma-Aldrich) and $1 \%$ penicillin/streptomycin (Invitrogen,) was used to cultivate the cells, which were seeded at low density and grown for 2 weeks. After this period, the growth medium was supplemented by $1-$ $2 \%$ DMSO (Sigma-Aldrich) and cells were left in culture for another 2 weeks, until reaching differentiation. The growth medium was renewed every 2 or 3 days. Differentiated HepaRG cells were exposed to xenobiotics for $24 \mathrm{~h}$ at which point their RNA was extracted.

Male and female C57/black6 mice were obtained from IFFA Credo, France. All animals received humane care in compliance with institutional guidelines. All experiments on human tissue were in accordance with ethical standards of the responsible committee on human experimentation and with the Helsinki Declaration. Hepatocytes from human and mouse liver were isolated and cultivated as previously described (De Sousa et al., 1991). Briefly, after isolation, cell viability was determined as at least $80 \%$ by the Erythrosine B exclusion test. Hepatocytes were seeded onto type-1collagen-coated dishes and cultured in medium I (William's E medium, 10\% FBS, $50 \mathrm{UI} / \mathrm{ml}$ penicillin, $50 \mathrm{Ag} / \mathrm{ml}$ streptomycin and $0.1 \mathrm{UI} / \mathrm{ml}$ insulin) for $24 \mathrm{~h}$. Then, medium I was replaced by a similar one deprived of serum and supplemented with hydrocortisone hemisuccinate $(1 \mu \mathrm{M})$ and bovine serum albumin $(240 \mu \mathrm{g} / \mathrm{ml})$. Cells were treated through the culture medium $24 \mathrm{~h}$ post-plating with $0.1,1$ and $10 \mu \mathrm{M}$ of each pesticide or their mixture prepared in DMSO, giving a final concentration of $0.05 \%$ of this vehicle. The chosen doses were adapted to cell culture on the basis of ADI established for humans as follows: Values expressed in $\mathrm{mg} / \mathrm{kg}$ of body weight/day were converted to $\mu \mathrm{g} / \mathrm{ml}$ of cell culture medium by assimilation to plasma concentration after complete transfer of the corresponding amount of pesticide in vivo (it was considered an individual of $60 \mathrm{~kg}$ with $5 \mathrm{~L}$ of blood). Controls received similar amounts of DMSO alone. ADI for atrazine, chlorpyrifos and endosulfan are $0.006,0.01$ and $0.006 \mathrm{mg} / \mathrm{kg}$ of $\mathrm{BW} /$ day, respectively (according to EPA).

\subsection{Gene expression profiling using cell stress and toxicity qPCR-based maccroarrays}

The modulation of 84 genes, targeting pathways of cell stress and toxicity in mice (namely, oxidative or metabolic stress, heat shock, proliferation and carcinogenesis, growth arrest and senescence, inflammation, necrosis, apoptosis and DNA damage and repair), was studied using arrays based on quantitative RT-PCR (qPCR)-analysis ( $\mathrm{RT}^{2}$ Profiler ${ }^{\mathrm{TM}}$; SA Biosciences, a QIAGEN Company, Courtaboeuf, France), performed according to the manufacturer's protocol. The array used in this study (catalogue Refs. PAMM-003D) consisted of a 96-well plate containing primers optimized for amplification of the targeted genes, plus five housekeeping genes and seven internal controls, including evaluation of reverse transcription, qPCR and gDNA removal efficiencies. Hepatocytes were prepared as described above from three male and three female mice and treated for $24 \mathrm{~h}$ with 1 or $10 \mu \mathrm{M}$ of either each pesticide, or the mixture, or DMSO for controls. Total RNA extraction was performed on each sample using the RNeasy Plus mini ${ }^{\circledR}$ kit from QIAGEN which includes a gDNA removal step.
RNA concentration was estimated using a NanoDrop (Thermo Scientific, Wilmington, DE, USA), while RNA integrity and quality were controlled by both the spectrophotometric 260/280 ratio (higher than 2.0) and the 28S/18S ratio (close to 1.8) using an Agilent 2100 Bioanalyzer. $1 \mu \mathrm{g}$ of total RNA from each individual was converted into cDNA using the $\mathrm{RT}^{2}$ First Strand Kit from SA Biosciences/QIAGEN. RT ${ }^{2}$ Real-Time SYBR Green/ROX PCR Master Mix, specifically designed for the ABI Prism 7000 thermocycler used, was added to the cDNA and an equal volume of $25 \mu \mathrm{l}$ was distributed to each of the 96 wells of the array. Amplification was conducted with an initial 10 -min hot start step at $95^{\circ} \mathrm{C}$ followed by 40 cycles at $95{ }^{\circ} \mathrm{C}$ for $15 \mathrm{~s}$ and $60^{\circ} \mathrm{C}$ for $1 \mathrm{~min}$. A dissociation curve was run after 40 cycles to verify single product formation. Experiments were performed in triplicate for each treatment. Data were imported into an MS-Excel sheet with macros provided by the manufacturer. For each PCR reaction, normalized average $C_{\mathrm{t}}$ values, a paired $t$ test $p$-value and a fold change were calculated. Analysis of relative gene expression data was performed using the $2-\Delta \Delta \mathrm{Ct}$ method (Livak and Schmittgen, 2001) after normalization of the raw data to five housekeeping genes included in the PCR-array (namely, glucuronidase $\beta$, hypoxanthine guanine phosphoribosyl transferase 1, HSP90ab1, Gapdh and Actin $\beta$ ). Any gene with a $C_{t}$ value of 35 or more was considered absent. Statistical analysis was performed on the data from three independent experiments using a Student's $t$-test provided by the manufacturer in the macros. Genes differentially expressed were retained when the $P$ value was $\leqslant 0.05$ (noted $^{*}$ ) and |fold change| $\geqslant 1.5$ following the different treatments.

\subsection{Quantitative RT-PCR analysis}

Independently from macroarrays, expression of several genes was determined or controlled through individual RT-PCR analyzes. Thus real-time PCR analyzes were performed to compare RNA expression of Cyp3A4, Bcl2, Hsp70 and Hsp90 on cells treated with similar and higher concentrations of pesticides. RNA isolation and cDNA synthesis were performed as described before (Zucchini-Pascal et al., 2009) from at least three independent cultures. Real-time PCR analysis was performed using LightCycler ${ }^{\circledR} 480$ Probes Master (Roche) as specified by the manufacturer, together with the FAMlabeled hydrolysis probes from the Universal ProbeLibrary Set, Human (Roche). Intron spanning primers were designed using the Universal ProbeLibrary Assay design center (http://www.universalprobelibrary.com). Calculations were performed using Gapdh as the endogenous control reference gene and, in the case of samples obtained from HepaRG cells, TBP. Fold difference in gene expression was calculated using the LightCycler software, taking into account the efficiency of the standard curve obtained with the second derivative maximum method.

\subsection{Western blot analysis}

Primary cultures of human and mouse hepatocytes were treated for $48 \mathrm{~h}$ with increased concentrations of atrazine, endosulfan, chlorpyrifos and the mix ACE $(0.1,1$ and $10 \mu \mathrm{M})$. Hepatocytes were lysed in a hypotonic buffer (25 mM HEPES, pH 7.5, $5 \mathrm{mM} \mathrm{MgCl}_{2}$, $5 \mathrm{mM}$ EDTA, $5 \mathrm{mM}$ DTT, $2 \mathrm{mM}$ PMSF, $10 \mu \mathrm{g} / \mathrm{ml}$ leupeptin, $10 \mu \mathrm{g} /$ $\mathrm{ml}$ pepstatin $\mathrm{A}$ ) supplemented with $0.1 \% \mathrm{SDS}$. Total protein concentration was determined using a bicinchoninic acid (BCA) protein assay kit (Pierce) from a bovine serum albumin (BSA) standard curve. Protein electrophoresis was performed in either $10 \%$ or $12 \%$ SDS-polyacrylamide gels with $50 \mu$ g protein loaded to each line. The proteins were then transferred onto a PVDF membrane (Amersham Life Science, Buckinghamshire, UK). After blocking with $5 \%$ non-fat skimmed milk in TBS-T $(10 \mathrm{mM}$ Tris/ $/ \mathrm{HCl}$, pH 7.5 , $140 \mathrm{mM} \mathrm{NaCl}, 0.1 \%$ Tween 20) for $1 \mathrm{~h}$ at $37^{\circ} \mathrm{C}$, membranes were 
A

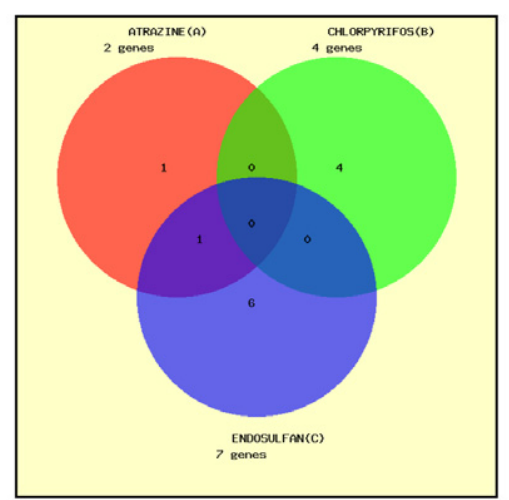

\begin{tabular}{|c|c|c|c|c|c|}
\hline \multicolumn{2}{|c|}{$\mathbf{A}$} & \multicolumn{2}{|c|}{ C } & \multicolumn{2}{|c|}{$\mathbf{E}$} \\
\hline Gene & ${ }^{a} \mathrm{FC}$ & Gene & ${ }^{a} \mathbf{F C}$ & Gene & ${ }^{a} \mathbf{F C}$ \\
\hline Chek2 & 2.0 & Atm & 1.6 & Chek2 & 1.6 \\
\hline \multirow[t]{6}{*}{ Cyp7a1 } & 1.9 & Ccl4 & 1.5 & Сур2с29 & 13.0 \\
\hline & & Hspa5 & 1.5 & Cyp3a11 & 5.1 \\
\hline & & Tnsf10 & 1.7 & Fmo1 & -1.9 \\
\hline & & & & Gstm3 & 8.8 \\
\hline & & & & Sod1 & 1.5 \\
\hline & & & & Sod2 & 1.6 \\
\hline
\end{tabular}

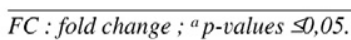

$B^{14}$

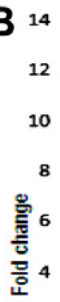

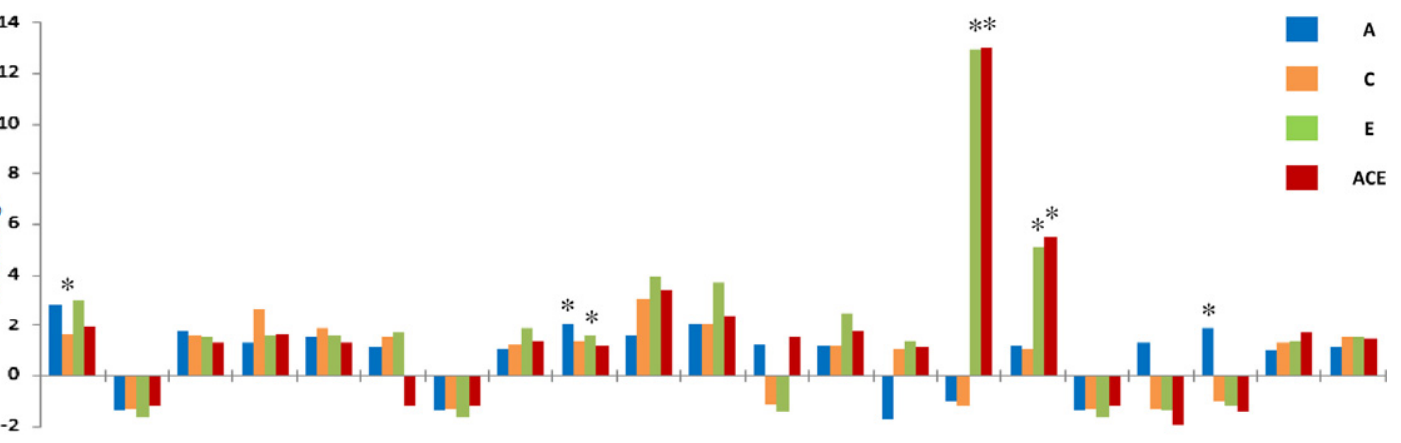

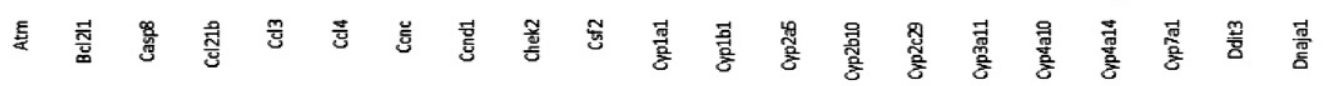

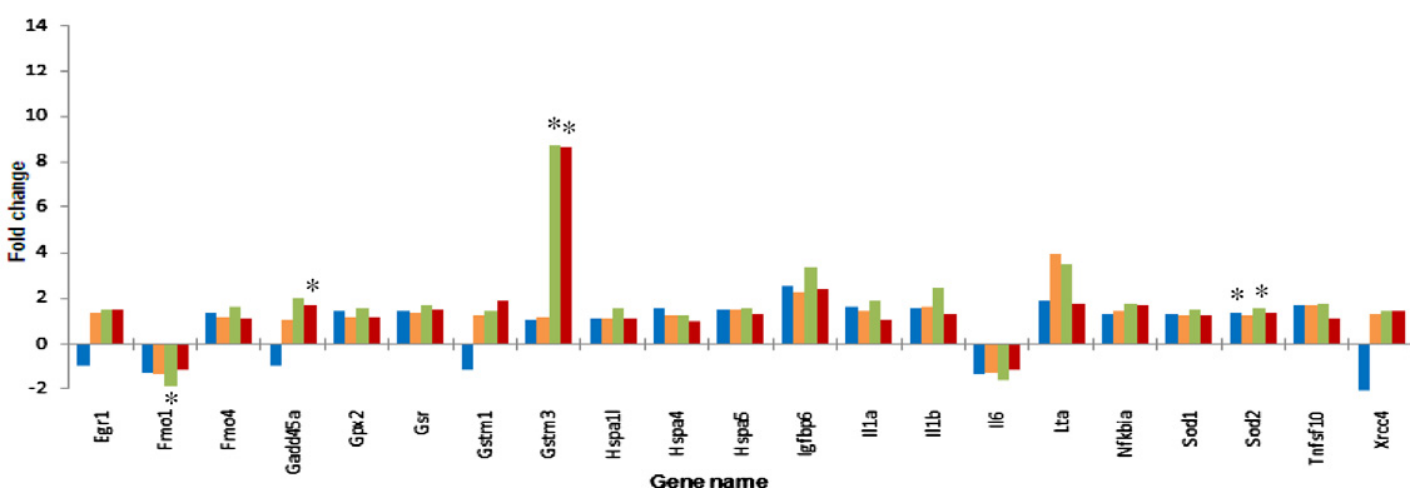

Fig. 1. Stress and toxicity pathways-related genes expression profile in female mice hepatocytes exposed to 3 pesticides and their mixture. Pesticides tested are A, atrazine; $C$, chlorpyrifos; E, endosulfan and ACE mixture of A + C + E. Cells were exposed to $1 \mu \mathrm{M}$ of $\mathrm{A}, \mathrm{C}$, E or ACE introduced in the culture medium. 84 gene expression levels were evaluated using the RT2 Profiler ${ }^{\mathrm{TM}}$ real time quantitative PCR (qPCR)-based array in three independent cultures of female mice hepatocytes. (A) Relative expression of genes significantly modulated by each pesticide separately. Left panel shows Venn representation of genes significantly modulated by the single pesticide treatments. Right panel shows fold changes in corresponding genes modulation. (B) Genes modulated by the different treatments in the oxidative and metabolic stress pathway selected among the array outcomes. Data were obtained from three independent biological replicates. Cts obtained from qPCRs (average was calculated and SD never exceeded 3\%) were normalized against selected most stable housekeeping genes (five were available). Each treated samples was compared to corresponding control. Statistical analysis of gene expression was performed as mentioned in the methods, using a specific EXCEL macro furnished by the manufacturer. Briefly, a Student's $t$-test was performed and only modulations with $P$-values $\leqslant 0.05\left({ }^{*}\right)$ were considered. Reliability of the data was also supported by several internal quality controls including the qPCR array reproducibility, control of reverse transcription quality and evaluation of possible genomic DNA contaminations. All the controls were passed successfully for the presented analyzes.

washed and incubated with the primary antibody in TBS-T containing 3\% BSA. After washing, membranes were incubated with horseradish peroxidase-conjugated secondary antibody (anti-mouse immunoglobulin $\mathrm{G}$ or anti-rabbit immunoglobulin $\mathrm{G}$, Promega, Madison, WI, USA). The signals were detected using Immobilon Western Detection Reagents (Millipore, Molsheim, France) and acquired using a CCD camera (ChemiGenius2, SynGene). Then, semi-quantification was performed using the GeneTools analysis software.

\subsection{Statistical analysis}

Data are expressed as means \pm standard deviation (S.D.) and determined from at least 3 independent experiments (cultures).
For qRT-PCR analysis and Western blot quantification, statistical significance of differences between various samples was determined using a Student's t-test. The levels of probability are noted $\left({ }^{*} P<0.05\right.$ or $\left.{ }^{* *} P<0.01\right)$.

\section{Results}

3.1. Effects of pesticides on the modulation of genes involved in stress and toxicity pathways

The modulation of 84 genes involved in cell stress and toxicity pathways was studied on primary cultures of male and female mice hepatocytes (Figs. 1 and 2) and human HepG2 and HepaRG 


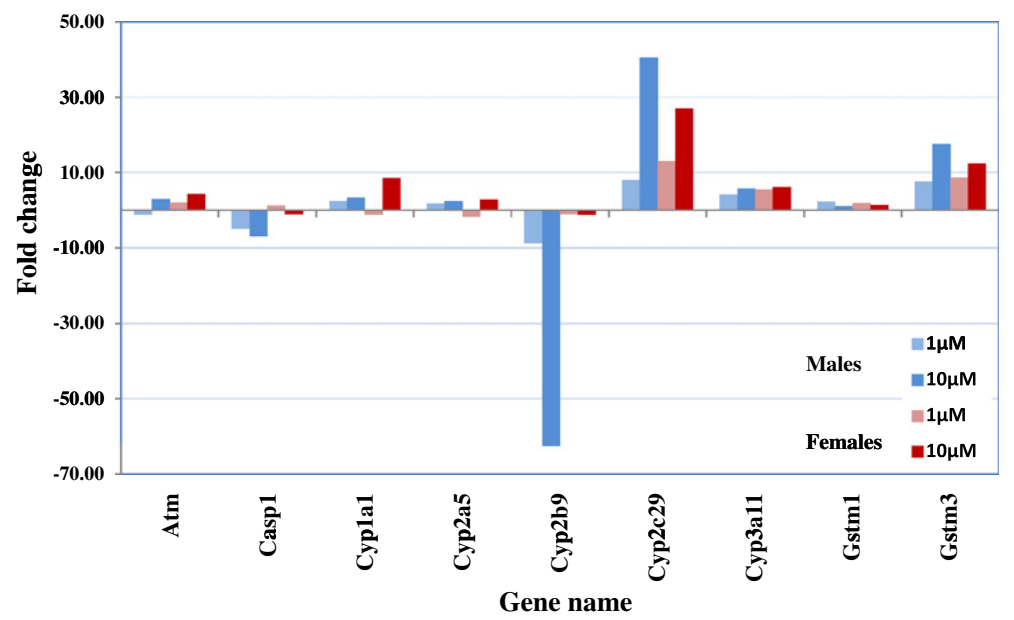

\begin{tabular}{ccccc}
\hline \multirow{2}{*}{ Gene } & \multicolumn{2}{c}{ Males } & \multicolumn{2}{c}{ Females } \\
\cline { 2 - 5 } & $\mathbf{1} \boldsymbol{\mu} \mathbf{M}$ & $\mathbf{1 0} \boldsymbol{\mu} \mathbf{M}$ & $\mathbf{1} \boldsymbol{\mu} \mathbf{M}$ & $\mathbf{1 0} \boldsymbol{\mu} \mathbf{M}$ \\
\hline Atm & -1.19 & 2.97 & 1.94 & 4.32 \\
Casp1 & -4.97 & -6.87 & 1.20 & -1.03 \\
Cyp1a1 & 2.37 & 3.26 & -1.16 & 8.46 \\
Cyp2a5 & 1.77 & 2.42 & -1.79 & 2.81 \\
Cyp2b9 & -8.78 & -62.52 & -1.08 & -1.24 \\
Cyp2c29 & 7.96 & 40.54 & 12.98 & 26.95 \\
Cyp3a11 & 4.17 & 5.69 & 5.49 & 6.06 \\
Gstm1 & 2.30 & 1.10 & 1.91 & 1.37 \\
Gstm3 & 7.58 & 17.59 & 8.65 & 12.37 \\
\hline
\end{tabular}

Fig. 2. Sex differences in modulation of stress and toxicity pathways-related genes in mice hepatocytes exposed to the combination of three pesticides (ACE). The treatment is introduced in the culture medium. Two concentrations of the mixture were tested: 1 and $10 \mu \mathrm{M}$. The graph presents the main genes modulated by the treatments after analysis (as described in the legend of Fig. 1 ). ${ }^{*} P$-value $\leqslant 0.05$ on at least three replicates.

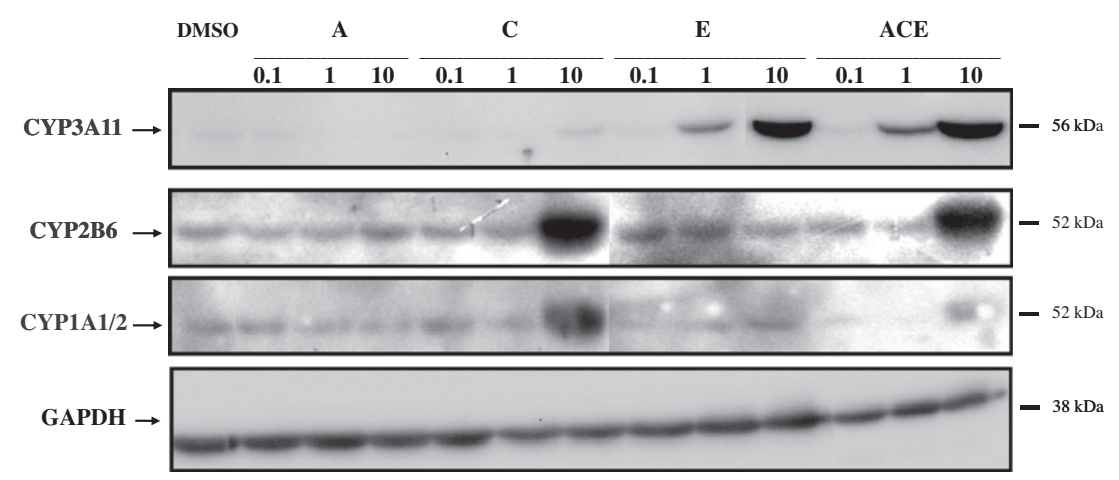

Fig. 3. Effects of pesticides and their mixture on the CYP expression level in mouse hepatocytes. Primary cultured mouse hepatocytes were treated with increased concentrations $(0.1,1$ and $10 \mu \mathrm{M})$ of A, C, E and the mix ACE for $48 \mathrm{~h}$. Then, cells were lysed and CYP3A11, CYP2B6, CYP1A1/2 and Gapdh protein levels were analysed by Western blot as described in experimental procedures (results representative of three experiments).

hepatocarcinoma cell line after exposure to either each pesticide separately (atrazine: A, chlorpyrifos: C, endosulfan E) or their equimolar mixture (ACE).

Fig. 1 shows data obtained from female mice hepatocytes exposed to $1 \mu \mathrm{M}$ pesticides as compared to controls treated with DMSO. In these cells, exposure to A, C or E separately induces 12 significant gene up- or down regulations, most of them being pesticide-specific, and only one being common to $A$ and $E$ treatments (Fig. 1A). Exposure to ACE does not clearly reveal synergic, additive or antagonistic effects (Fig. 1B).

Main modulated genes which are over expressed (exceeding a twofold change threshold) belong to the oxidative and metabolic stress pathway. Indeed, both E and ACE induce a similar over expression of Cyp2c29, Cyp3a11 and Gstm3 of about 13, 5 and 9fold, respectively (Fig. 1A), showing a predominance of $E$ impact on female mouse hepatocytes. An additional over expression (twofold change) of Chek2, a key gene involved in DNA damage and repair, is found under A exposure. When the threshold was reduced to 1.5 -fold-change, additional genes belonging to the same or other pathways appear significantly over expressed by A (Cyp7a1 from the metabolic pathway), C ( $\mathrm{Cl} / 4$ involved in inflammation, Atm in cell growth and DNA damage, and Tnfsf10 in apoptosis signaling), E (Check 2 involved in DNA damage), and ACE (Gstm1, Sod1 and Sod2 from the metabolic pathway and Gadd45 involved in growth arrest). One gene, Fmo1, involved in metabolic stress, is found about two fold down regulated after E exposure. The other genes remain globally unchanged after the different treatments.

Sex-related differences have been pointed out in our animal model. Investigating ACE exposure $(1$ and $10 \mu \mathrm{M})$ on male and female mice, we observe modulations common to male and female mice in term of pathways (specificity for the stress and metabolism pathway). Main genes which are found over expressed (Cyp2c29, Cyp3a11 and Gstm3) are similarly modulated in males and females (Fig. 2). On the contrary, Cyp2b9 and Caspase1 gene expressions are found specifically down-modulated in males, while about stable in females. It should be noticed that increasing pesticides dose to $10 \mu \mathrm{M}$ leads to emphasize the modulations observed at $1 \mu \mathrm{M}$ for the main genes cited above, except for Cyp3a11 which remains unchanged (Fig. 2).

\subsection{Effects of pesticides treatments on CYPs enzymes expression}

Based upon our transcriptional studies, we investigated to confirm the effects of pesticides and their mixture on the detoxification process. Therefore, exposure to the three pesticides alone or in mixture was tested by Western blot at concentrations of $0.1,1$ and $10 \mu \mathrm{M}$ on human and mouse hepatocytes and HepaRG cells. In mouse hepatocytes, endosulfan is found able to induce CYP3A11 in a dose-dependent manner. Similar effects are found in cells treated with the mixture (Fig. 3). Chlorpyrifos strongly induces CYP2B6 
A

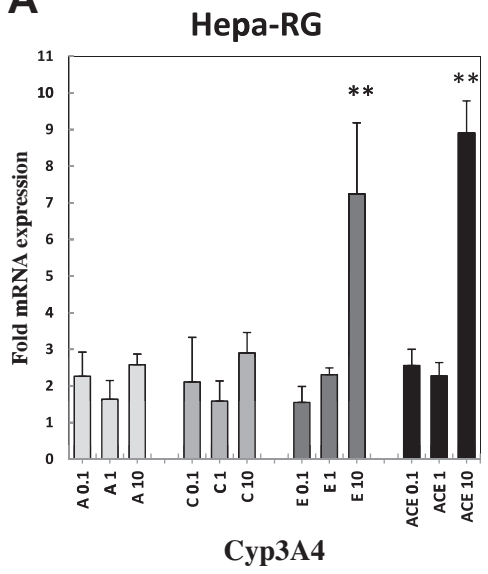

B

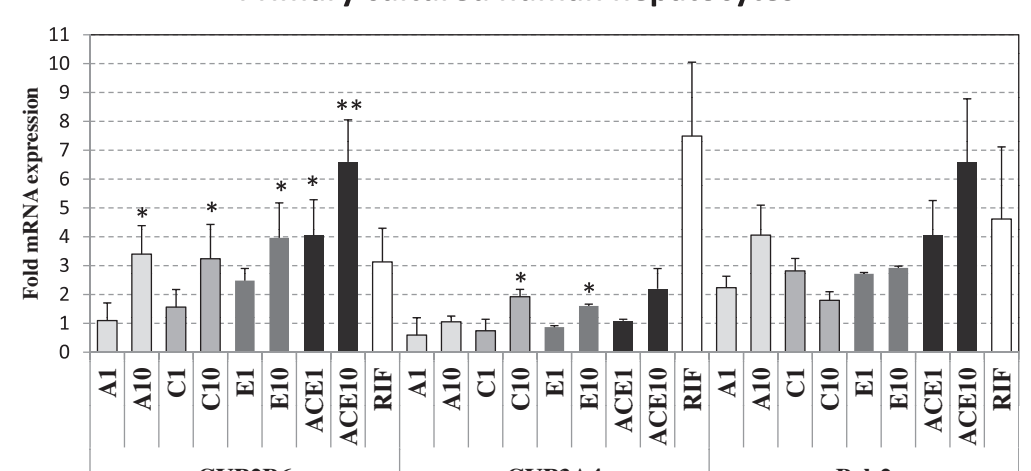

CYP2B6
Bcl-2

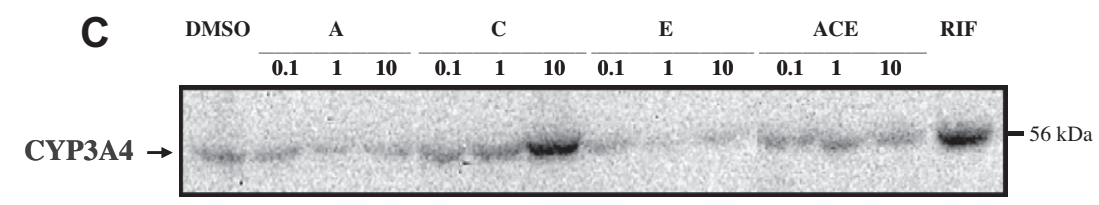

Fig. 4. Effects of pesticides and their mixture on the expression of genes under PXR/CAR control in human liver cells. Primary cultured human hepatocytes or HepaRG cells were treated with increased concentrations $(0.1,1$ and $10 \mu \mathrm{M})$ of A, C, E and the mix ACE and $10 \mu \mathrm{M}$ rifampicin. (A) Modulation of the Cyp3A4 gene expression in HepaRG cells. Differentiated HepaRG cells were exposed to the aforementioned compounds for $24 \mathrm{~h}$ after which real-time quantitative PCR was performed as mentioned in the methods section. (B) Real-time quantitative PCR was used to quantify the mRNA of Cyp2b6, Cyp3a4 and bcl-2 in human hepatocytes exposed to the pesticides for 24 h. (C) Western blot analysis of CYP3A4 and Gapdh protein levels in human hepatocytes treated for $48 \mathrm{~h}$ as described above. Experimental conditions are described in experimental procedures. Results are representative of three independent experiments. Data are expressed as the mean $\pm S . D,{ }^{*} P<0.05$ and ${ }^{* *} P<0.01$ obtained by Student $t$-test.

A

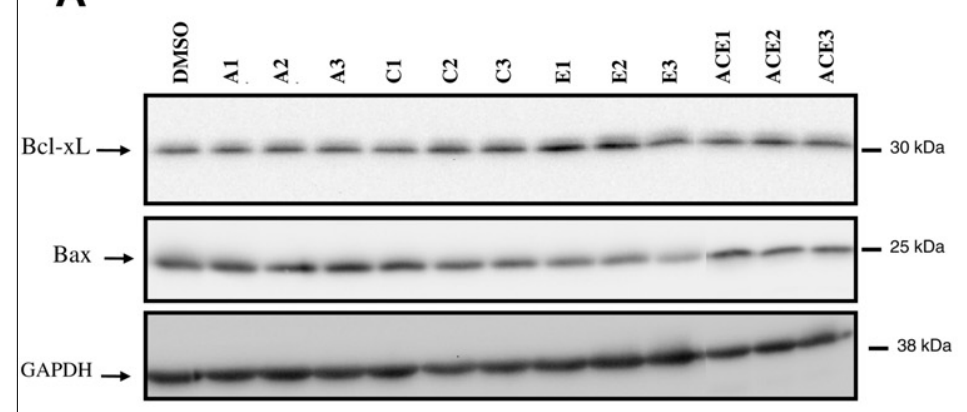

C

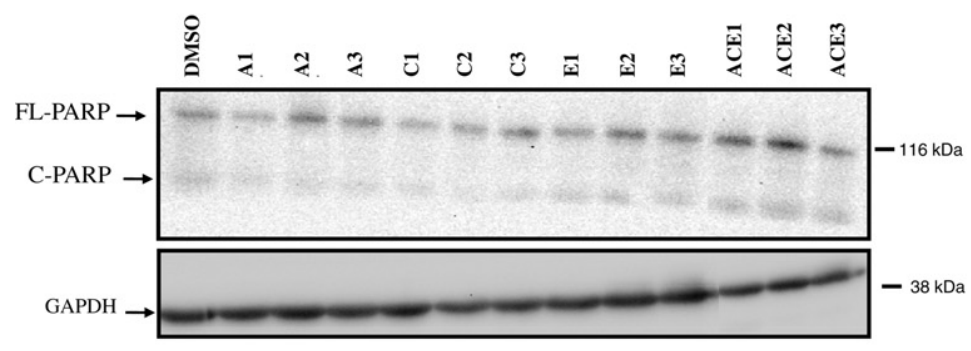

B

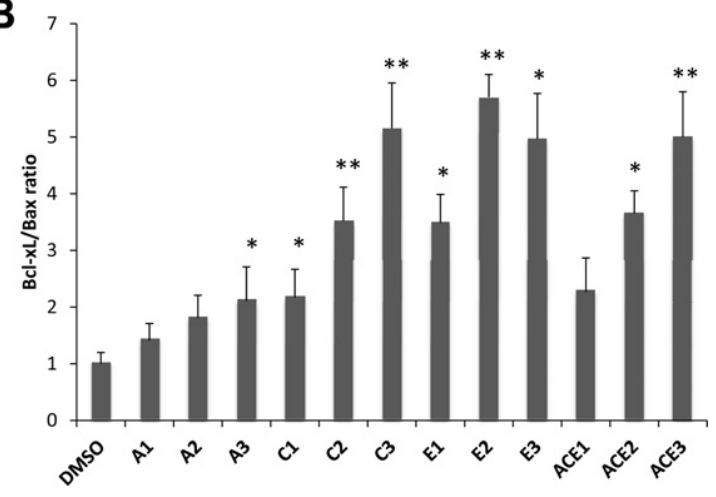

D

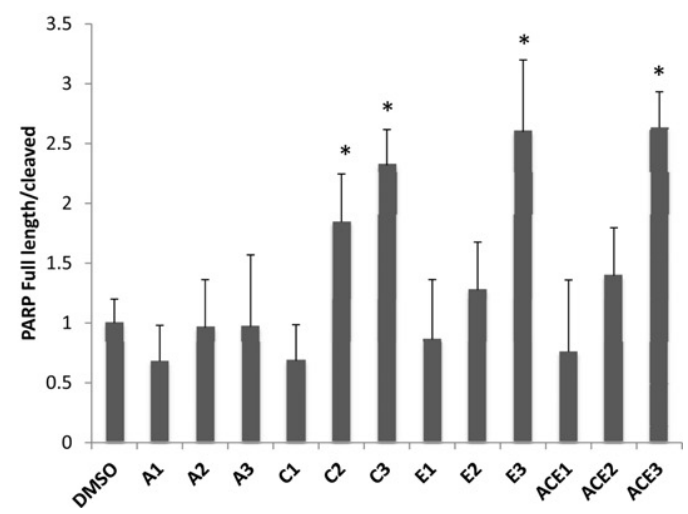

Fig. 5. Effects of pesticides and their mixture on the apoptotic regulation process. Primary cultured mouse hepatocytes were treated with increased amounts of pesticides A, $\mathrm{C}, \mathrm{E}$ and the mix ACE for $48 \mathrm{~h}(0.1,1$ and $10 \mu \mathrm{M}$ concentrations are represented by letter indexes 1,2 and 3 on the graph, respectively). Bcl-xL, Bax, PARP (full-length and cleaved fragments) and Gapdh protein levels were analysed by Western blot (A and C) on cell lysates as described in experimental procedures (results representative of three independent experiments). The semi-quantification of chemiluminescence was performed after the acquisition with a CCD camera. The Bcl-xL/Bax ratio (B) and the PARP full length/cleaved ratio (D) were calculated from band densitometry measured on three independent experiments (means \pm S.D.) after normalization by DMSO-control cells value and Gapdh. 
and CYP1A1/2 but only at the higher dose $(10 \mu \mathrm{M})$. As found with endosulfan, the modulation pattern of CYP2B6 by chlorpyrifos is found similar with the mixture. This was not the case for CYP1A1/2 whose effect strongly diminishes when chlorpyrifos is combined with the other pesticides. Atrazine has no effect on any of the CYPs tested in our conditions.

HepaRG cells have, by now, become well established in toxicology, as one of the best models of human hepatic cells in toxicological evaluation of xenobiotics in terms of enzyme expression (Gripon et al., 2002; Aninat et al., 2006). Utilizing quantitative PCR, we evaluated the modulation of CYP3A4 gene expression, following the treatment of differentiated cells with three different final concentrations $(0.1,1$ and $10 \mu \mathrm{M})$ of individual pesticides and the ternary mixture. CYP3A4 was found to be up regulated 9and 10 -fold in the case of treatment with E and ACE (Fig. 4 A), respectively.

Modulations observed on mouse hepatocytes were different on human cells where only CYP3A is induced by chlorpyrifos and the mixture in a dose dependent manner. Indeed, human hepatocytes seem to be more sensitive to chlorpyrifos than to endosulfan (Fig. 4B and C). No effect is observed with atrazine treatment in either human or murine hepatocytes (not shown).

\subsection{Effects of pesticides treatments on the apoptotic process}

In previous studies we have demonstrated that PXR activation leaded to induced and spontaneous apoptosis inhibition (Zucchini et al., 2005). Indeed, this nuclear receptor regulates Bcl-2 and Bcl$\mathrm{xL}$, two anti-apoptotic members of the Bcl-2 gene family. Accordingly, we sought to evaluate whether A, C, E and the mixture ACE affected spontaneous apoptosis in mouse hepatocytes (Fig. 5). As shown in Fig. 5, A, C, E and ACE increase the protein level of Bcl$\mathrm{xL}$ in a concentration-dependent manner. This increase is accompanied by a down-regulation of the pro-apoptotic protein family member Bax (Fig. 5A). Pro- and anti-apoptotic members of the Bcl-2 family act predominantly by counteracting each other through heterodimerization, establishing the protein ratio between these two subsets such as a rheostat for the suicide program. A, C, E, and ACE increase the $\mathrm{Bcl}-\mathrm{xL} / \mathrm{Bax}$ ratio at protein level in a concentration-dependent manner (Fig. 5B), attesting the anti-apoptotic potential of these compounds. Although no significant effects were observed on apoptosis-linked caspase activities (data not shown), C, E and ACE inhibited the cleavage of the poly (ADP-ribose) polymerase (PARP) protein (Fig. 5C and D). This enzyme of $116 \mathrm{kDa}$ (involved in DNA damage and repair) is a substrate of caspase- 3 that cleaves it to generate a fragment of $89 \mathrm{kDa}$. Hence, we observe a slight but significant increase of the full length/cleaved protein ratio when mouse hepatocytes were cultivated in the presence of $\mathrm{C}, \mathrm{E}$ and ACE. These results confirm the anti-apoptotic tendency of these xenobiotics. It is interesting to note that the effect of the mixture ACE is strictly the same that of the most potent pesticide.

\section{Discussion}

In toxicological evaluation of xenobiotics, phenotypical modifications associated with medium- and even long-term exposure to low or very low doses of pesticides are rarely observed in experimental models in vivo. Moreover, the sole cell survival, which is a commonly used parameter in toxicology, often becomes a hardly significant marker of possible effects. Chronic or variable types of exposures are additional time-dependant factors which render evaluations even more complicated. Multiple targets (DNA, proteins, or signaling and metabolic pathways) may be affected, up- or down-modulating the severity of the effects (additivity, antagonism, reversibility, cell adaptability). Thus, wishing to increase the knowledge on the topic, it becomes absolutely necessary to analyze cellular reactions at molecular level. Consequently, studying the activation of key nuclear receptors such as PXR and CAR or the modulation of main actors of cell stress and toxicity pathways constitute an essential step in trying to understand and anticipate the impact of pesticides on cellular homeostasis and metabolism, especially in a key organ such as the liver.

Our data first show that, well below the NOAEL established in vivo, pesticides can induce significant gene modulations in primary cultures of male and female mice hepatocytes. The three compounds tested mainly affected metabolic enzymes (i.e., two CYPs and a glutathione S-transferase). CYPs are key proteins of the cell detoxification process and represent approximately 2-4\% of total protein in human liver. The most abundant isotype in this organ is CYP3A (29\%) followed by CYP2C (18\%), CYP1A2 (13\%), CYP2B6 (1-10\% due to notable inter-individual variability) and CYP2E1 (7\%). It is to be noted that the slightly represented CYP2D6 $(<2 \%)$, accounts for the metabolism of almost $30 \%$ of all drugs (Mizutani et al., 2005; Stresser et al., 1999).

Interestingly, we found the major CYP3A gene family to be clearly over expressed by low doses of endosulfan in mouse and human cells. CYP3A, which has been estimated to be responsible for metabolization of about $50 \%$ of drugs metabolized by CYPs in humans (Bertz and Granneman, 1997), is prototypical among a battery of genes activated by PXR (Urquhart et al., 2007). CYP3A modulations observed in the present work are in accordance with those recently described in a study demonstrating PXR activation by endosulfan both in human cells in vitro and in mice in vivo (Casabar et al., 2010).

Increasing evidence made clear that CAR and PXR show broad and often overlapping functions (Moore et al., 2000; Williams et al., 2005). Indeed, species-dependent assymmetrical regulation of CYP3A and CYP2B gene by PXR and CAR has been described by some authors, involving cross-talk between the two nuclear receptors (Moore et al., 2000; Faucette et al., 2006). Recent studies describing induction of Cyp3a11 and Gstm3 under treatment by the potent PXR activator pregnenolone-16 $\alpha$-carbonitrile (PCN) in mice (Cui et al., 2010), or showing CYP3A to be inhibited in CAR-null mice (Mota et al., 2010, Braeuning et al., 2009), clearly support our data. Thus, it is conceivable that the activation of these genes by endosulfan observed in our study follows a regulatory mechanism involving both PXR and CAR. Unlike other PXR/CAR activators such as rifampicine, chlotrimazole or phenobarbital (Moore et al., 2000), endosulfan seems to modulate CYP3A both in mouse and human cells, thus suggesting an involvement of similar mechanism in the two species.

Estrogen-like endocrine disruption effect of endosulfan has previously described by our team (Lemaire et al., 2006). Besides their induction by the pregnenolone derivative PCN (Cui et al., 2010), Cyp3a11, Cyp2c29 and Gstm3 were also shown to be over expressed under nonylphenol (an environmental estrogen) exposure in a CAR-dependent manner (Hernandez et al., 2009). Hence, such similarities between these data and our present findings suggest involvement of the PXR/CAR-dependent machinery in this endosulfan toxic effect.

As similar estrogenic properties have been mentioned for chlorpyrifos in a screening study on human MCF-7 cells exposed to various pesticides (Andersen et al., 2002), it could be assumed that overlapping activation of several pathways by endosulfan and chlorpyrifos explain the differential expression of CYP1A and CYP3A4 that we observe in human hepatic cells exposed to $C$ alone or mixed in ACE. Again, some lack of correspondence between respective modulation of gene and protein expressions (i.e., CYP2B6 and $\mathrm{Bcl} 2$ ) observed in western blot analyzes may be 
related to the complexity of regulatory mechanisms involved as suggested by some authors (Gry et al., 2009).

We observe other gene modulations under exposure to the three pesticides indicating interference with the DNA damage and repair pathway. One of them, the Atm gene involved in the pro-apoptotic process, displays a protein kinase activity and controls the rate of cells growth. It was described to interact with other proteins such as BRCA1 to respond to DNA-damage (Cortez et al., 1999). In our experiments, other genes like Gadd45a and Tnfsf10 (TRAIL) are also found modified by treatments at low doses, revealing occurrence of a control/retro control on and around this pathway. Moreover, C, E and ACE show to inhibit the cleavage of the PARP protein involved in DNA damage and repair. Due to similarity among mouse and human data mentioned above, we sought possible involvement of the three pesticides in an apoptotic process. Indeed, in a previous study we found that PXR promoted cell survival through $\mathrm{Bcl}-2$ or $\mathrm{Bcl}-\mathrm{xL}$ regulation and proposed a model where PXR coordinately regulates phase I, II, III and anti-apoptotic proteins, so as to protect hepatocytes from the harmful effects of endo- and xenobiotics (Zucchini et al., 2005). Based upon these results and the literature, we suggested that PXR serves as a physiological sensor that coordinately regulates gene expression in the liver to promote its survival. The present study seems to confirm this hypothesis and reveal possible involvement of complex cross-regulating processes.

In conclusion, our data show a good correlation between mouse and human hepatocytes in primary cultures regarding deregulation of genes encoding metabolic and detoxification pathways enzymes. They globally confirm the occurrence of molecular changes in expression and regulation pathways under low doses of residual contaminants, and reveal the anti-apoptotic tendency of the three pesticides tested with a predominance of the effects for chlorpyrifos and endosulfan. It is interesting to note that the effect of the mixture ACE mimicked that of the most potent pesticide. Even though only slight perturbations are observed, our study shows that early disturbance of DNA damage and apoptosis pathways are effective at low and mixed doses of residual pesticides. Such disturbances in a context of chronic exposure may possibly favor occurrence of pathologies in humans. Further development of long term in vivo studies is needed to assess such hypothesis.

On a regulatory point of view, such studies, when enriched with investigations on the patterns of exposure and the underlying variability within the human population, help in better understanding the links between metabolic perturbations and animal toxicology data, thus improving the evaluation of the risks to human health posed by exposures to mixtures of residual pesticides and other environmental contaminants.

\section{Conflict of interest}

None declared.

\section{Acknowledgements}

This work has been supported by the French National Research Agency (ANR) through the "Food-human nutrition" program (PNRA) program (project ANR-07-PNRA-006-01). Many thanks to Laurence Gamet-Payrastre for helpful discussions.

\section{References}

Abadi-Korek, I., Stark, B., Zaizov, R., Shaham, J., 2006. Parental occupational exposure and the risk of acute lymphoblastic leukemia in offspring in Israel. J. Occup. Environ. Med. 48, 165-174.

Ackerman, F., 2007. The economics of atrazine. Int. J. Occup. Environ. Health 13, 441-449.
Alavanja, M.C., Hoppin, J.A., Kamel, F., 2004. Health effects of chronic pesticide exposure: cancer and neurotoxicity. Annu. Rev. Public Health 25, 155-197.

Andersen, H.R., Vinggaard, A.M., Rasmussen, T.H., Gjermandsen, I.M., BonefeldJørgensen, E.C., 2002. Effects of currently used pesticides in assays for estrogenicity, androgenicity, and aromatase activity in vitro. Toxicol. Appl. Pharmacol. 179 (1), 1-12.

Aninat, C., Piton, A., Glaise, D., Le Charpentier, T., Langouët, S., Morel, F., GuguenGuillouzo, C., Guillouzo, A., 2006. Expression of cytochromes P450, conjugating enzymes and nuclear receptors in human hepatoma HepaRG cells. Drug Metab. Dispos. 34 (1), 75-83.

Baldi, I., Cantagrel, A., Lebailly, P., Tison, F., Dubroca, B., Chrysostome, V., Dartigues, J.F., Brochard, P., 2003. Association between Parkinson's disease and exposure to pesticides in southwestern France. Neuroepidemiology 22, 305-310.

Bebe, F.N., Panemangalore, M., 2003. Exposure to low doses of endosulfan and chlorpyrifos modifies endogenous antioxidants in tissues of rats. J. Environ. Sci. Health B 38 (3), 349-363.

Bertz, R.J., Granneman, G.R., 1997. Use of in vitro and in vivo data to estimate the likelihood of metabolic pharmacokinetic interactions. Clin. Pharmacokinet. 32 (3), 210-258

Braeuning, A., Sanna, R., Huelsken, J., Schwarz, M., 2009. Inducibility of drugmetabolizing enzymes by xenobiotics in mice with liver-specific knockout of Ctnnb1. Drug Metab. Dispos. 37 (5), 1138-1145.

Calabrese, E.J., 2010. Hormesis is central to toxicology, pharmacology and risk assessment. Hum. Exp. Toxicol. 29 (4), 249-261.

Casabar, R.C., Das, P.C., Dekrey, G.K., Gardiner, C.S., Cao, Y., Rose, R.L., Wallace, A.D., 2010. Endosulfan induces CYP2B6 and CYP3A4 by activating the pregnane $X$ receptor. Toxicol. Appl. Pharmacol. 245 (3), 335-343.

Chade, A.R., Kasten, M., Tanner, C.M., 2006. Nongenetic causes of Parkinson's disease. J. Neural. Transm. Suppl., 147-151.

Chakraborti, T.K., Farrar, J.D., Pope, C.N., 1993. Comparative neurochemical and neurobehavioral effects of repeated chlorpyrifos exposures in young and adult rats. Pharmacol. Biochem. Behav. 46 (1), 219-224.

Colosio, C., Birindelli, S., Corsini, E., Galli, C.L., Maroni, M., 2005. Low level exposure to chemicals and immune system. Toxicol. Appl. Pharmacol. 207, 320-328.

Cooper, R.L., Stoker, T.E., Tyrey, L., Goldman, J.M., McElroy, W.K., 1999. Atrazine disrupts the hypothalamic control of pituitary-ovarian function. Toxicol. Sci. 53, 297-307.

Cortez, D., Wang, Y., Qin, J., Elledge, S.J., 1999. Requirement of ATM-dependent phosphorylation of brca1 in the DNA damage response to double-strand breaks. Science 286 (5442), 1162-1166.

Cui, J.Y., Gunewardena, S.S., Rockwell, C.E., Klaassen, C.D., 2010. ChIPing the cistrome of PXR in mouse liver. Nucleic Acids Res. 38 (22), 7943-7963.

Cummings, A.M., Rhodes, B.E., Cooper, R.L., 2000. Effect of atrazine on implantation and early pregnancy in four strains of rats. Toxicol. Sci. 58, 135-143.

De Sousa, G., Dou, M., Barbe, D., Lacarelle, B., Placidi, M., Rahmani, R., 1991. Freshly isolated or cryopreserved human hepatocytes in primary culture: influence of drug metabolism on hepatotoxicity. Toxicol. In Vitro 5 (5-6), 483-486.

Eldridge, J.C., Stevens, J.T., Breckenridge, C.B., 2008. Atrazine interaction with estrogen expression systems. Rev. Environ. Contam. Toxicol. 196, 147-160.

Faucette, S.R., Sueyoshi, T., Smith, C.M., Negishi, M., Lecluyse, E.L., Wang, H., 2006. Differential regulation of hepatic CYP2B6 and CYP3A4 genes by constitutive androstane receptor but not pregnane X receptor. J. Pharmacol. Exp. Ther. 317, 1200-1209.

Galloway, T., Handy, R., 2003. Immunotoxicity of organophosphorous pesticides. Ecotoxicology 12 (1-4), 345-363.

Gripon, P., Rumin, S., Urban, S., Le Seyec, J., Glaise, D., Cannie, I., Guyomard, C., Lucas, J., Trepo, C., Guguen-Guillouzo, C., 2002. Infection of a human hepatoma cell line by hepatitis B virus. Proc. Natl. Acad. Sci. USA 99 (24), 15655-15660.

Gry, M., Rimini, R., Strömberg, S., Asplund, A., Pontén, F., Uhlén, M., Nilsson, P., 2009. Correlations between RNA and protein expression profiles in 23 human cell lines. BMC Genomics 10, 365.

Gupta, P.K., Chandra, S.V., 1977. Toxicity of endosulfan after repeated oral administration to rats. Bull. Environ. Contam. Toxicol. 18 (3), 378-384.

Hack, R., Leist, K.H., 1995. Chronic toxicity and carcinogenicity studies with the insecticide endosulfan in rats and mice. Food Chem. Toxicol. 33 (11), 941-950.

Haviland, J.A., Butz, D.E., Porter, W.P., 2010. Long-term sex selective hormonal and behavior alterations in mice exposed to low doses of chlorpyrifos in utero. Reprod. Toxicol. 29 (1), 74-79.

Hayes, T.B., Collins, A., Lee, M., Mendoza, M., Noriega, N., Stuart, A.A., Vonk, A., 2002. Hermaphroditic, demasculinized frogs after exposure to the herbicide atrazine at low ecologically relevant doses. Proc. Natl. Acad. Sci. USA 99 (8), 5476-5480.

Hernandez, J.P., Mota, L.C., Huang, W., Moore, D.D., Baldwin, W.S., 2009. Sexually dimorphic regulation and induction of $\mathrm{P} 450$ s by the constitutive androstane receptor (CAR). Toxicology 256 (1-2), 53-64.

Jia, Z., Misra, H.P., 2007. Exposure to mixtures of endosulfan and zineb induces apoptotic and necrotic cell death in SH-SY5Y neuroblastoma cells, in vitro. J. Appl. Toxicol. 27, 434-446.

Lee, W.J., Sandler, D.P., Blair, A., Samanic, C., Cross, A.J., Alavanja, M.C., 2007. Pesticide use and colorectal cancer risk in the Agricultural Health Study. Int. J. Cancer 121 (2), 339-346.

Lemaire, G., Mnif, W., Mauvais, P., Balaguer, P., Rahmani, R., 2006. Activation of alpha- and beta-estrogen receptors by persistent pesticides in reporter cell lines. Life Sci. 79 (12), 1160-1169.

Lemaire, G., Terouanne, B., Mauvais, P., Michel, S., Rahmani, R., 2004. Effect of organochlorine pesticides on human androgen receptor activation in vitro. Toxicol. Appl. Pharmacol. 196 (2), 235-246. 
Lim, S., Ahn, S.Y., Song, I.C., Chung, M.H., Jang, H.C., Park, K.S., Lee, K.U., Pak, Y.K., Lee, H.K., 2009. Chronic exposure to the herbicide, atrazine, causes mitochondrial dysfunction and insulin resistance. PLoS One 4 (4), e5186.

Liu, B., Gao, H.M., Hong, J.S., 2003. Parkinson's disease and exposure to infectious agents and pesticides and the occurrence of brain injuries: role of neuroinflammation. Environ. Health Perspect. 111, 1065-1073.

Livak, K.J., Schmittgen, T.D., 2001. Analysis of relative gene expression data using real-time quantitative PCR and the 2(-Delta Delta C(T)) Method. Methods 25 (4), 402-408.

Lutz, W.K., 2002. Differences in individual susceptibility to toxic effects of chemicals determine the dose-response relationship and consequences of setting exposure standards. Toxicol. Lett. 126 (3), 155-158.

Mahajan, R., Blair, A., Lynch, C.F., Schroeder, P., Hoppin, J.A., Sandler, D.P., Alavanja, M.C., 2006. Fonofos exposure and cancer incidence in the agricultural health study. Environ. Health Perspect. 114, 1838-1842.

Mendola, P., Selevan, S.G., Gutter, S., Rice, D., 2002. Environmental factors associated with a spectrum of neurodevelopmental deficits. Ment. Retard. Dev. Disabil. Res. Rev. 8, 188-197.

Mizutani, T., Shinoda, M., Tanaka, Y., et al., 2005. Autoantibodies against CYP2D6 and other drug-metabolizing enzymes in autoimmune hepatitis type 2. Drug Metab. Rev. 37 (1), 235-252.

Moore, L.B., Parks, D.J., Jones, S.A., Bledsoe, R.K., Consler, T.G., Stimmel, J.B., Goodwin, B., Liddle, C., Blanchard, S.G., Willson, T.M., Collins, J.L., Kliewer, S.A., 2000. Orphan nuclear receptors constitutive androstane receptor and pregnane $\mathrm{X}$ receptor share xenobiotic and steroid ligands. J. Biol. Chem. 275 (20), 1512215127.

Mota, L.C., Hernandez, J.P., Baldwin, W.S., 2010. Constitutive androgen receptor-nul mice are sensitive to the toxic effects of parathion: association with reduced cytochrome p450-mediated parathion metabolism. Drug Metab. Dispos. 38 (9), $1582-1588$.

Navarro, H.A., Basta, P.V., Seidler, F.J., Slotkin, T.A., 2001. Neonatal chlorpyrifos administration elicits deficits in immune function in adulthood: a neural effect? Brain Res. Dev. Brain Res. 130 (2), 249-252.

Paul, V., Balasubramaniam, E., Jayakumar, A.R., Kazi, M.A., 1995. Sex-related difference in the neurobehavioral and hepatic effects following chronic endosulfan treatment in rats. Eur. J. Pharmacol. 293 (4), 355-360.

Perez-Carreon, J.I., Dargent, C., Merhi, M., Fattel-Fazenda, S., Arce-Popoca, E., VillaTreviño, S., Rouimi, P., 2009. Tumor promoting and co-carcinogenic effects in medium-term rat hepatocarcinogenesis are not modified by co-administration of 12 pesticides in mixture at acceptable daily intake. Food Chem. Toxicol. 47 (3), 540-546

Purdue, M.P., Hoppin, J.A., Blair, A., Dosemeci, M., Alavanja, M.C., 2007. Occupational exposure to organochlorine insecticides and cancer incidence in the agricultura health study. Int. J. Cancer 120 (3), 642-649.

Rao, M., Narayana, K., Benjamin, S., Bairy, K.L., 2005. L-ascorbic acid ameliorates postnatal endosulfan induced testicular damage in rats. Indian J. Physiol Pharmacol. 49 (3), 331-336.

Rodriguez, V.M., Thiruchelvam, M., Cory-Slechta, D.A., 2005. Sustained exposure to the widely used herbicide atrazine: altered function and loss of neurons in brain monoamine systems. Environ. Health Perspect. 113, 708-715.

Rowe, A.M., Brundage, K.M., Barnett, J.B., 2008. Developmental immunotoxicity of atrazine in rodents. Nordic Pharmacol. Soci. Basic Clin. Pharmacol. Toxicol. 102 $139-145$

Rowe, A.M., Brundage, K.M., Schafer, R., Barnett, J.B., 2006. Immunomodulatory effects of maternal atrazine exposure on male Balb/c mice. Toxicol. Appl. Pharmacol. 214 (1), 69-77.
Ruder, A.M., Waters, M.A., Carreón, T., Butler, M.A., Davis-King, K.E., Calvert, G.M., Schulte, P.A., Ward, E.M., Connally, L.B., Lu, J., Wall, D., Zivkovich, Z., Heineman, E.F. Mandel,J.S., Morton, R.F., Reding, D.J., 2006. Brain Cancer Collaborative Study Group. The Upper Midwest Health Study: a case-control study of primary intracranial gliomas in farm and rural residents. J. Agric. Saf. Health 12 (4), 255-274.

Rusiecki, J.A., De Roos, A., Lee, W.J., Dosemeci, M., Lubin, J.H., Hoppin, J.A., Blair, A. Alavanja, M.C., 2004. Cancer incidence among pesticide applicators exposed to atrazine in the Agricultural Health Study. J. Natl. Cancer Inst. 96, 1375-1382.

Scremin, O.U., Chialvo, D.R., Lavarello, S., Berra, H.H., Lucero, M.A., 2011. The environmental pollutant endosulfan disrupts cerebral cortical function at low doses. Neurotoxicology 32 (1), 31-37.

Siddiqui, M.K., Anjum, F., Qadri, S.S., 1987. Some metabolic changes induced by endosulfan in hepatic and extra hepatic tissues of rat. J. Environ. Sci. Health B 22 (5), 553-564.

Silva, M.H., Gammon, D., 2009. An assessment of the developmental and reproductive neurotoxicity of endosulfan. Birth Defects Res. B Dev. Reprod. Toxicol. 86 (1), 1-28.

Singh, S.K., Pandey, R.S., 1990. Effect of sub-chronic endosulfan exposures on plasma gonadotrophins, testosterone, testicular testosterone and enzymes of androgen biosynthesis in rat. Indian J. Exp. Biol. 28 (10), 953-956.

Sinha, N., Narayan, R., Saxena, D.K., 1997. Effect of endosulfan on the testis of growing rats. Bull. Environ. Contam. Toxicol. 58 (1), 79-86.

Stanko, J.P., Enoch, R.R., Rayner, J.L., Davis, C.C., Wolf, D.C., Malarkey, D.E., Fenton, S.E., 2010. Effects of prenatal exposure to a low dose atrazine metabolite mixture on pubertal timing and prostate development of male Long-Evans rats. Reprod. Toxicol. 30 (4), 540-549.

Stresser, D.M., Kupfer, D., 1999. Monospecific antipeptide antibody to cytochrome P-450 2B6. Drug Metab. Dispos. 27 (4), 517-525.

Thrasher, J.D., Heuser, G., Broughton, A., 2002. Immunological abnormalities in humans chronically exposed to chlorpyrifos. Arch. Environ. Health 57 (3), 181187.

Urquhart, B.L., Tirona, R.G., Kim, R.B., 2007. Nuclear receptors and the regulation of drug-metabolizing enzymes and drug transporters: implications for interindividual variability in response to drugs. J. Clin. Pharmacol. 47 (5), 566-578.

Villanueva, C.M., Durand, G., Coutte, M.B., Chevrier, C., Cordier, S., 2005. Atrazine in municipal drinking water and risk of low birth weight, preterm delivery, and small-for-gestational-age status. Occup. Environ. Med. 62, 400-405.

Weselak, M., Arbuckle, T.E., Wigle, D.T., Krewski, D., 2007. In utero pesticide exposure and childhood morbidity. Environ. Res. 103, 79-86.

Whitney, K.D., Seidler, F.J., Slotkin, T.A., 1995. Developmental neurotoxicity of chlorpyrifos: cellular mechanisms. Toxicol. Appl. Pharmacol. 134 (1), 53-62.

Williams, S.N., Dunham, E., Bradfield, C.A., 2005. Induction of cytochrome p450 enzymes. In: Ortiz de Montellano, P.R. (Ed.), Cytochrome P450: Structure, Mechanism, and Biochemistry, third ed. Kluwer Academic/Plenum Publishers, New York, pp. 323-346.

Wilson, V.S., LeBlanc, G.A., 1998. Endosulfan elevates testosterone biotransformation and clearance in CD-1 mice. Toxicol. Appl. Pharmacol. 148 (1), 158-168.

Zucchini, N., de Sousa, G., Bailly-Maitre, B., Gugenheim, J., Bars, R., Lemaire, G., Rahmani, R., 2005. Regulation of Bcl-2 and Bcl-xL anti-apoptotic protein expression by nuclear receptor PXR in primary cultures of human and rat hepatocytes. Biochim. Biophys. Acta 1745, 48-58.

Zucchini-Pascal, N , de Sousa, G. Rahmani, R. 2009. Lindane and cell death: at the crossroads between apoptosis, necrosis and autophagy. Toxicology 256 (1-2), $32-41$. 